\title{
NUTRITIONAL POTENTIAL OF FENUGREEK SUPPLEMENTED BREAD WITH SPECIAL REFERENCE TO ANTIOXIDANT PROFILING
}

\author{
Bahzad Afzal ${ }^{1}$, Imran Pasha ${ }^{1, *}$, Tahir Zahoor ${ }^{1}$ and Haq Nawaz ${ }^{2}$ \\ ${ }^{1}$ National Institute of Food Science \& Technology, University of Agriculture, Faisalabad, Pakistan; \\ ${ }^{2}$ Institute of Animal Nutrition and Feed Technology, University of Agriculture, Faisalabad, Pakistan. \\ "Corresponding author's e-mail: ipasha2001@uaf.edu.pk
}

\begin{abstract}
Globally, fenugreek (Trigonella foenum-graecum) is well recognized for imparting flavor to several traditional foods. Besides, it provides tremendous amount of active ingredients for health promotion and disease prevention. Purposely, the present research work was designed to elucidate nutritional \& antioxidant potential of fenugreek seeds and their incorporation in bread formulation @ 5, 10 \& 15\%. The supplementation of fenugreek seed powder @ 15\% in designed bread increased total phenolic content from $99.00 \pm 4.45$ (control) to $413.00 \pm 19.82 \mathrm{mg}$ GAE$/ 100 \mathrm{~g}$ whereas, increment in flavonoid contents was up to $2.91 \pm 0.12 \mathrm{mg} \mathrm{CE} / \mathrm{g}$ as compared to control (2.13 \pm 0.09$)$. Alongside, it was found effective in increasing antioxidant activity i.e. evaluated through DPPH, FRAP and $\beta$-carotene assays as $51.00 \pm 2.39 \%, 450.00 \pm 21.60 \mu \mathrm{mol}$ $\mathrm{Fe}^{2+} / \mathrm{g}$ and $43.00 \pm 2.10 \%$, respectively. However, $10 \%$ supplementation of fenugreek seed powder presented better sensory response of the prepared bread. All these outcomes have revealed that supplementation of fenugreek seed powder in bread serve as functional food accredited to rich nutritional, antioxidant $\&$ sensory quality.

Keywords: Nutritional profile, antioxidant, total phenolic content, flavonoids, bread
\end{abstract}

\section{INTRODUCTION}

The recent era has witnessed the coinage of lifestyle related malfunctions due to poor dietary habits, altering lifestyles and elevated consumption of refined and processed foods. The prevalence of metabolic dysfunctions has identified as a dominating factor for unhealthy living. In this regard, herbs and spices are in limelight to develop certain products that improve the health status besides provision of basic nutrition (Liu et al., 2007; Sethi et al., 2008). Fenugreek (Trigonella foenum-graecum) locally known as methi, is a member of legume family originated from Asia and South Eastern Europe while presently it is ubiquitous in Pakistan, India and Egypt (Betty, 2008). Globally, fenugreek leaves and seeds powder are recommended in food formulations and serve as medicinal herb, coffee alternative, insect repellent in grain storage \& employed in fragrance manufacturing industries (Ahari et al., 2009The fenugreek seeds contain 25.2-30.1\% protein, $7.2-9.3 \%$ lipids, $20.1-25.3 \%$ insoluble fiber, 20.4$30.2 \%$ galactomannan and $5.3-7.3 \%$ saponins along with ample amounts of volatile oils, free amino acids, mucilaginous fiber and flavonoids (Raju and Bird, 2006). It contains lysine \& L-tryptophan rich protein, mucilaginous fiber and other important chemical constituents such as sapogenins, saponins, nicotinic acid, coumarin, phytic acid, fenugreekine, trigonelline and scopoletin that are supposed to be for its beneficial health effects. Phenolic compounds, for instance, through their antioxidant activity, are hypothesized to have cancer suppressing ability. It also comprises alkaloids of pyridine-type, generally trigonelline (0.21-0.35\%), choline $(0.51 \%)$, carpaine and gentianine, the flavonoids; apigenins, orientin, quercetin, rutin, free amino acids; such as hydroxyisoleucine, histidine, arginine \& lysine, minerals; iron \& calcium and glycosides that yield steroids on hydrolysis i.e. tigogenin, yamogenin and neotigogenin (Mehrafarin et al., 2010).

Flour containing fenugreek seeds powder has good attribute for bakery products and now a day's wheat flours have been supplemented with fenugreek seeds for achieving better results in developing number of food menus (Hooda and Jood, 2004). The present study was planned to evaluate the nutritional \& antioxidant worth of fenugreek grown in Pakistan and to develop functional bread with the addition of fenugreek seeds powder.

\section{MATERIALS AND METHODS}

Procurement of raw materials: Wheat variety Lasani 2011 and fenugreek seeds (Qasoori methi) were procured from Ayub Agricultural Research Institute (AARI), Faisalabad, Pakistan.

Preparation of raw materials: The wheat was cleaned by sieving followed by tempering. Afterwards, milling was carried out using Quadrumate Senior mill to get straight grade flour. Likewise, fenugreek seeds were cleaned by screening and washing, followed by drying and grinding to get fine powder. The resultant powder was stored in air tight containers prior to analysis. Composite flours were prepared 
with the addition of $5,10 \& 15 \%$ of fenugreek seeds powder in wheat flour.

\section{Analysis of raw material and composite flours:}

Chemical analysis: Chemical composition of wheat flour and fenugreek seeds powder was estimated by determining moisture, ash, crude protein, crude fat, crude fiber and nitrogen free extract (NFE) according to the prescribed methods of AACC (2000).

Extraction of polyphenols: The polyphenols from composite flours were extracted by following the protocol of Rusak et al. (2008) using ethanol at constant temperature of $60^{\circ} \mathrm{C}$ for 48 hours. Resultant extracts were filtered using vacuum filtration assembly and solvents were recovered by Rotary Evaporator (EYELA, N-N series, Japan) at a temperature of $40^{\circ} \mathrm{C}$. The extraction yield was calculated and resultant extracts were stored at $4^{\circ} \mathrm{C}$ until used, afterwards the extracts were subjected to different assays.

\section{Phytochemical Profiling:}

Total phenolic content: Total phenolics of resultant extracts were estimated through spectrophotometer (Irmeco, Germany) following Folin-Ciocalteau method (Singleton et al., 1999). The extract (I mL) was mixed with $0.5 \mathrm{~mL}$ of Folin- Ciocalteau reagent along with $7.5 \mathrm{~mL}$ of distilled water and allowed to stand for $20 \mathrm{~min}$. Following resting period, 1.5 $\mathrm{mL}$ of sodium bicarbonate solution $(7 \%)$ was added to the mixture. Then stay for 20 min by placing sample tubes in water bath $\left(40^{\circ} \mathrm{C}\right)$, took $0.5 \mathrm{ml}$ from this solution and add 2 $\mathrm{mL}$ of distilled water and absorbance was measured at $755 \mathrm{~nm}$ using a UV/Vis Spectrophotometer (CECIL, CE7200) against control. Total polyphenols were calculated and expressed as Gallic acid equivalent (mg Gallic acid/100 g).

Total Flavonoids: Total flavonoids were determined following the procedure by Zhishen et al. (1999). Took two $\mathrm{mL}$ of aqueous extract in a $10 \mathrm{~mL}$ volumetric flask, then added $5 \mathrm{~mL}$ of distilled water followed by $0.3 \mathrm{~mL}$ of $5 \%$ $\mathrm{NaNO}_{2}$ and after $5 \mathrm{~min}-0.6 \mathrm{~mL}$ of $10 \% \mathrm{AlCl}_{3}$ was added. After another 5 min stay $2 \mathrm{~mL}$ of $1 \mathrm{M} \mathrm{NaOH}$ was added and volume was made upto $10 \mathrm{~mL}$ with distilled water. Take one $\mathrm{mL}$ from this solution after mixing this solution, add $9 \mathrm{~mL}$ distilled water and measured absorbance by using spectrophotometer at $510 \mathrm{~nm}$. Total flavonoids were expressed as Catechin equivalents per dry matter.

Antioxidant Activity:

Free radical scavenging activity (DPPH assay): The DPPH radical scavenging activity of all extracts was measured according to the procedure of Oktay et al. (2003). Purposely, $1 \mathrm{~mL}$ of DPPH was added to each extract $(4 \mathrm{~mL})$ and incubated at room temperature for $30 \mathrm{~min}$. The absorbance was noted at $520 \mathrm{~nm}$ using Spectrophotometer. Percent inhibition was calculated using the following formula;
$\mathrm{AB}=$ absorbance of blank sample $(\mathrm{t}=0 \mathrm{~min})$

$\mathrm{AA}=$ absorbance of tested extract solution $(\mathrm{t}=30 \mathrm{~min})$ B-carotene and linoleic acid assay: Total antioxidant activity of the extracts was monitored using assay based on coupled oxidation of $\beta$-carotene and linoleic acid (Adegoke $e t$ al. 1998). Briefly, $2 \mathrm{mg}$ of $\beta$-carotene was dissolved in 20 $\mathrm{mL}$ chloroform along with $40 \mathrm{mg}$ linoleic acid and $400 \mathrm{mg}$ Tween 20. After removing chloroform, $3 \mathrm{~mL}$ of the prepared emulsion was added in $0.10 \mathrm{~mL}$ sample and placed in a water bath for $120 \mathrm{~min}$. Oxidation of $\beta$-carotene was determined through spectrophotometer at $470 \mathrm{~nm}$.

Ferric reducing antioxidant power (FRAP assay): The ferric reducing ability of all the extracts was measured according to the procedures of Benzie and Strain (1996). Purposely, extract $(0.5 \mathrm{~mL})$ was mixed with phosphate buffer $(1.25 \mathrm{~mL}, 0.2 \mathrm{M}$, $\mathrm{pH}$ 6.6) and potassium ferricyanide $(1.25 \mathrm{~mL}, 1 \%)$. After incubation, $1.25 \mathrm{~mL}$ of $10 \%$ trichloroacetic acid (TCA) was added along with $0.1 \%$ ferric chloride and then left at room temperature for $10 \mathrm{~min}$. Sample absorbance was measured with spectrophotometer at $700 \mathrm{~nm}$.

Bread preparation: For the purpose, respective flour, sugar, oil, yeast and water were used to make the bread (AACC, 2000; Method No. 10-09). After preparation, the bread was cooled and packed in polythene packages before further analyses.

Chemical analysis of bread: Chemical composition (moisture, ash, crude fat, crude fiber, crude protein and nitrogen free extract) of bread was determined by following the methods described in AACC (2000).

Phytochemical profiling of bread: Total phenolic content and flavonoids were performed for prepared bread by using procedures described by Singleton et al. (1999) and Zhishen et al. (1999), respectively as described above.

Antioxidant activity of bread: Free radical scavenging ability (Oktay et al., 2003), $\beta$-carotene and linoleic acid assay (Adegoke et al., 1998) and FRAP assay (Benzie and Strain, 1996) were also estimated for bread.

Sensory evaluation: The hedonic assessment of bread was carried out for sensory characteristics i.e. volume, color of crust, aroma, taste and overall acceptability by panel of six judges (Lawless and Heymann, 1998). The bread was examined for sensory evaluation using nine-point hedonic scale system ranged from extremely liking to disliking $(9=$ like extremely; 1 = dislike extremely) following the guidelines of Meilgaard et al. (2007). Panelists were provided separate booths equipped with white fluorescent light. To exclude any biasness from the experiment, samples were presented to the panel randomly and requested to assign scores for selected characteristics.

Reduction $=\frac{\mathrm{AB}-\mathrm{AA}}{\mathrm{AB}} \times 100$ 
Table 1. Chemical composition (\%) of raw material.

\begin{tabular}{lcc}
\hline Parameter & Wheat flour & Fenugreek seeds powder \\
\hline Moisture & $13.5 \pm 0.25$ & $10.65 \pm 0.53$ \\
Ash & $0.41 \pm 0.05$ & $4.14 \pm 0.21$ \\
Protein & $10.5 \pm 0.13$ & $22.86 \pm 1.14$ \\
Fat & $1.13 \pm 0.04$ & $6.98 \pm 0.35$ \\
Fiber & $0.31 \pm 0.04$ & $7.90 \pm 0.43$ \\
NFE & $74.15 \pm 2.42$ & $47.47 \pm 2.37$ \\
\hline
\end{tabular}

Values expressed are means \pm standard deviation

Statistical analysis: The collected data from the current study was subjected to statistical analysis by applying completely randomized design (CRD) using Cohort version 6.1 (Costat2003) according to guidelines of Steel et al. (1997).

\section{RESULTS}

Chemical composition of raw material given in Table 1, illustrated that fenugreek seed powder is substantial source of protein $(22.86 \pm 1.14 \%)$ and crude fiber $(7.90 \pm 0.43 \%)$ followed by ash content $(4.14 \pm 0.21 \%)$. Total phenolic content (TPC) among different treatments with the addition of fenugreek seeds powder was found to be $305.00 \pm 14.03$ $\mathrm{mg} \mathrm{GAE} / 100 \mathrm{~g}\left(\mathrm{~T}_{1}\right), 410.00 \pm 19.27 \mathrm{mg} \mathrm{GAE} / 100 \mathrm{~g}\left(\mathrm{~T}_{2}\right)$ and $450.00 \pm 22.05 \mathrm{mg}$ GAE $/ 100 \mathrm{~g}\left(\mathrm{~T}_{3}\right)$. The flavonoids in different treatments were found in range of $2.38 \pm 0.08 \mathrm{mg}$ $\mathrm{CE} / \mathrm{g}\left(\mathrm{T}_{0}\right)$ to $3.01 \pm 0.14 \mathrm{mg} \mathrm{CE} / \mathrm{g}\left(\mathrm{T}_{3}\right)$. The free radical scavenging activity (DPPH) of treatments increased with increasing percentage of fenugreek i.e. $\mathrm{T}_{3}(58.00 \pm 2.84 \%)$ followed by $\mathrm{T}_{2}(53.00 \pm 2.49 \%), \mathrm{T}_{1}(49.00 \pm 2.25 \%)$ and $\mathrm{T}_{0}$ $(35.00 \pm 1.57 \%)$. The ferric reducing ability (FRAP) values in different treatments as a function of fenugreek seeds powder addition in wheat flour ranged from 222.00 $\pm 9.99\left(\mathrm{~T}_{0}\right)$ to $501.00 \pm 24.54 \mu \mathrm{mol} \mathrm{Fe} 2^{+} / \mathrm{g} \quad\left(\mathrm{T}_{3}\right)$. Different treatments depicted that $\beta$-carotene values ranged from $33.00 \pm 1.48 \%$ $\left(\mathrm{T}_{0}\right)$ to $51.00 \pm 2.49 \%\left(\mathrm{~T}_{3}\right)$.

The effect of supplementation of fenugreek seeds powder in bread illustrated chemical composition as $34.49 \pm 1.06$ to $34.63 \pm 1.17 \%$ moisture, $1.39 \pm 0.07$ to $1.72 \pm 0.06 \%$ ash, $11.74 \pm 0.99$ to $12.79 \pm 1.06 \%$ protein, $6.25 \pm 0.23$ to $6.81 \pm 0.34 \%$ fat, $1.65 \pm 0.08$ to $2.29 \pm 0.11 \%$ fiber and $41.90 \pm 1.84$ to $44.35 \pm 2.08 \%$ NFE (Table 3 ). The highest TPC (413.00 $\pm 19.82 \mathrm{mg} \mathrm{GAE} / 100 \mathrm{~g}$ ) was found in $\mathrm{T}_{3}$ followed by $\mathrm{T}_{2}(341.00 \pm 16.02 \mathrm{mg} \mathrm{GAE} / 100 \mathrm{~g})$ and $\mathrm{T}_{1}(238.00 \pm 10.94 \mathrm{mg}$ GAE/100g). Total flavonoids for different treatments; $\mathrm{T}_{0}$ $(2.13 \pm 0.09 \mathrm{mg} \mathrm{CE} / \mathrm{g}), \mathrm{T}_{1}(2.50 \pm 0.10 \mathrm{mg} \mathrm{CE} / \mathrm{g}), \mathrm{T}_{2}(2.68 \pm 0.10$ $\mathrm{mg} \mathrm{CE} / \mathrm{g})$ and $\mathrm{T}_{3}(2.91 \pm 0.12 \mathrm{mg} \mathrm{CE} / \mathrm{g})$, depicted maximum results for treatment with $15 \%$ fenugreek seeds powder supplementation (Table 4). The values for free radical scavenging activity of different treatments ranged from $31.00 \pm 1.27$ to $51.00 \pm 2.39 \%$. As indicated from values, highest reducing power $\left(450.00 \pm 21.60 \mu \mathrm{mol} \mathrm{Fe}^{2+} / \mathrm{g}\right)$ was recorded in $15 \%$ seeds powder supplementation $\left(\mathrm{T}_{3}\right)$ while lowest $\left(167.00 \pm 7.01 \mu \mathrm{mol} \mathrm{Fe} e^{2+} / \mathrm{g}\right)$ in wheat flour $\left(\mathrm{T}_{0}\right)$. The maximum $\beta$-carotene value $43.00 \pm 2.10 \%$ was recorded in $\mathrm{T}_{3}$ followed by $\mathrm{T}_{2}(40.00 \pm 1.88 \%)$ and $\mathrm{T}_{1}(37.00 \pm 1.70 \%)$ while minimum $29.00 \pm 1.18 \%$ in $\mathrm{T}_{0}$ (Table 4 ).

The score for bread volume prepared with fenugreek seeds powder supplementation ranged from $7.02 \pm 0.09$ to $7.39 \pm 0.04$ (0 hours), $6.86 \pm 0.14$ to $7.21 \pm 0.13$ (24 hours), $6.74 \pm 0.09$ to $7.02 \pm 0.16$ (48 hours) and $5.57 \pm 0.04$ to $6.90 \pm 0.12$ (72 hours). The aroma of the bread ranged from $7.01 \pm 0.20$ to $7.26 \pm 0.18$ (0 hours), $6.77 \pm 0.12$ to $7.02 \pm 0.15$ (24 hours), $6.66 \pm 0.12$ to $6.81 \pm 0.16$ (48 hours) and $6.40 \pm 0.19$ to $6.74 \pm 0.12$ ( 72 hours) (Table 5). The sensory score for taste of bread varied from $6.91 \pm 0.15$ to $7.62 \pm 0.06$ ( 0 hours), $6.62 \pm 0.16$ to $7.23 \pm 0.13$ (24 hours), $6.36 \pm 0.13$ to $6.90 \pm 0.21$ (48 hours) and $6.24 \pm 0.11$ to $6.80 \pm 0.18$ (72 hours). The score for crust color of bread ranged from $7.01 \pm 0.15$ to $7.52 \pm 0.03$ ( 0 hours), $6.81 \pm 0.15$ to $7.28 \pm 0.16$ ( 24 hours), $6.66 \pm 0.12$ to $7.06 \pm 0.14$ (48 hours) and $6.62 \pm 0.14$ to $6.92 \pm 0.20$ (72 hours) (Table 6). The score for overall acceptability of bread ranged from $7.08 \pm 0.08$ to $7.46 \pm 0.15$ ( 0 hours), $6.83 \pm 0.18$ to $7.22 \pm 0.17$ ( 24 hours), $6.59 \pm 0.15$ to $7.07 \pm 0.14$ (48 hours) and $6.59 \pm 0.10$ to $6.89 \pm 0.10$ (72 hours) (Table 7).

\section{DISCUSSION}

The results of wheat flour analysis are in line with findings of Khan et al. (2009) and Mueen-ud-Din et al. (2009) who observed 11.78 to $13.42 \%$ moisture content, 0.41 to $0.55 \%$ ash content, 10.23 to $12.05 \%$ crude protein, 1.29 to $1.40 \%$ crude fat and 0.41 to $0.44 \%$ crude fiber in different Pakistani wheat varieties. The seeds of fenugreek had moisture content $(8.30 \%)$, ash content $(2.92 \%)$, crude protein $(24.60 \%)$, crude fat $(6.11 \%)$, crude fiber $(7.72 \%)$ and nitrogen free extract $(50.35 \%)$ (Mahfouz et al., 2012). Similarly, Yaser et al. (2013) found that fenugreek seeds contain $6.57 \%$ moisture, $4.03 \%$ total ash, $26.78 \%$ proteins, $6.35 \%$ lipids. $6.75 \%$ crude fiber and $49.52 \%$ carbohydrates. Findings of the present study are also correlated with the results of Kasaye and Jha (2015) who found fenugreek powder had crude protein (29.89\%), crude fat $(7.91 \%)$ crude fiber $(11.34 \%)$, carbohydrates $(51.55 \%)$ and ash content $(2.94 \%)$ on dry weight basis.

Fenugreek extract had polyphenols $(9.47 \mathrm{mg}$ GAE/g dry seeds) as major antioxidants (Dua et al., 2013) and antioxidant activity directly related with polyphenol content of fenugreek (Naidu et al., 2012). Similarly, total phenolic content in different fenugreek varieties were observed 127.8 to $139.2 \mathrm{mg} \mathrm{GAE} / 100 \mathrm{~g}$ (Ali et al., 2015). Flavonoids are diverse group of polyphenolic components with exceptional strength to act as free radical scavenger, anti-inflammatory and antibacterial agent (Premanath et al., 2011). Different solvents like methanol, ethanol, hexane, ethyl acetate and acetone were used for extraction and flavonoid content found as $607 \pm 3.6,653 \pm 4.3,208 \pm 4.2,251 \pm 3.3$ and $416 \pm 2.7$ 
Table 2. Antioxidants in different fenugreek supplemented flours

\begin{tabular}{lccccc}
\hline Treatment & $\begin{array}{c}\text { TPC } \\
(\mathbf{m g ~ G A E} / \mathbf{~ 1 0 0 g})\end{array}$ & $\begin{array}{c}\text { Flavonoids }(\mathbf{m g} \\
\mathbf{C E} / \mathbf{g})\end{array}$ & $\begin{array}{c}\text { DPPH } \\
(\boldsymbol{\%})\end{array}$ & $\begin{array}{c}\text { FRAP } \\
(\boldsymbol{\mu m o l ~ F e} \mathbf{m} \mathbf{g})\end{array}$ & $\begin{array}{c}\boldsymbol{\beta} \text {-carotene \& Linoleic } \\
\text { assay (\%) }\end{array}$ \\
\hline $\mathrm{T}_{0}$ & $117.00 \pm 5.26 \mathrm{c}$ & $2.38 \pm 0.08 \mathrm{c}$ & $35.00 \pm 1.57 \mathrm{c}$ & $222.00 \pm 9.99 \mathrm{c}$ & $33.00 \pm 1.48 \mathrm{c}$ \\
$\mathrm{T}_{1}$ & $305.00 \pm 14.03 \mathrm{~b}$ & $2.57 \pm 0.10 \mathrm{c}$ & $49.00 \pm 2.25 \mathrm{~b}$ & $421.00 \pm 19.36 \mathrm{~b}$ & $43.00 \pm 1.97 \mathrm{~b}$ \\
$\mathrm{~T}_{2}$ & $410.00 \pm 19.27 \mathrm{a}$ & $2.79 \pm 0.09 \mathrm{ab}$ & $53.00 \pm 2.49 \mathrm{ab}$ & $465.00 \pm 21.85 \mathrm{ab}$ & $45.00 \pm 2.11 \mathrm{~b}$ \\
$\mathrm{~T}_{3}$ & $450.00 \pm 22.05 \mathrm{a}$ & $3.01 \pm 0.14 \mathrm{a}$ & $58.00 \pm 2.84 \mathrm{a}$ & $501.00 \pm 24.54 \mathrm{a}$ & $51.00 \pm 2.49 \mathrm{a}$ \\
\hline
\end{tabular}

Values expressed are means \pm standard deviation; TPC: Total phenolic content, GAE: Gallic acid equivalents (Folin-Ciocalteu method), CE: Catechin equivalents, DPPH: 2,2-diphenyl-1-picrylhydrazyl, FRAP: Ferric reducing antioxidant powder; $\mathrm{T}_{0}$ : Wheat Flour (Control); $\mathrm{T}_{1}: 5 \%$ fenugreek seeds powder supplemented wheat flour; $\mathrm{T}_{2}: 10 \%$ fenugreek seeds powder supplemented wheat flour; $\mathrm{T}_{3}: 15 \%$ fenugreek seeds powder supplemented wheat flour.

Table 3. Chemical composition (\%) of different supplemented bread

\begin{tabular}{lllllll} 
Treatments & Moisture & Ash & Protein & Fat & Fiber & NFE \\
\hline $\mathrm{T}_{0}$ & $34.46 \pm 1.09 \mathrm{~d}$ & $1.24 \pm 0.02 \mathrm{~d}$ & $11.12 \pm 0.55 \mathrm{c}$ & $5.97 \pm 0.15 \mathrm{c}$ & $1.27 \pm 0.01 \mathrm{~d}$ & $45.49 \pm 1.42 \mathrm{a}$ \\
$\mathrm{T}_{1}$ & $34.49 \pm 1.06 \mathrm{c}$ & $1.39 \pm 0.07 \mathrm{c}$ & $11.74 \pm 0.99 \mathrm{~b}$ & $6.25 \pm 0.23 \mathrm{~b}$ & $1.65 \pm 0.08 \mathrm{c}$ & $44.35 \pm 2.08 \mathrm{~b}$ \\
$\mathrm{~T}_{2}$ & $34.56 \pm 1.35 \mathrm{~b}$ & $1.55 \pm 0.05 \mathrm{~b}$ & $12.32 \pm 1.20 \mathrm{ab}$ & $6.54 \pm 0.44 \mathrm{ab}$ & $1.99 \pm 0.11 \mathrm{~b}$ & $43.04 \pm 2.13 \mathrm{c}$ \\
$\mathrm{T}_{3}$ & $34.63 \pm 1.17 \mathrm{a}$ & $1.72 \pm 0.06 \mathrm{a}$ & $12.79 \pm 1.06 \mathrm{a}$ & $6.81 \pm 0.34 \mathrm{a}$ & $2.29 \pm 0.11 \mathrm{a}$ & $41.90 \pm 1.84 \mathrm{~d}$ \\
\hline
\end{tabular}

Values expressed are means \pm standard deviation; $\mathrm{T}_{0}$ : Wheat Flour (Control); $\mathrm{T}_{1}: 5 \%$ fenugreek seeds powder supplemented wheat flour; $\mathrm{T}_{2}$ : $10 \%$ fenugreek seeds powder supplemented wheat flour; $\mathrm{T}_{3}: 15 \%$ fenugreek seeds powder supplemented wheat flour.

Table 4. Antioxidants in different supplemented bread

\begin{tabular}{lccccc} 
Treatments & $\begin{array}{c}\text { TPC } \\
(\mathbf{m g ~ G A E} / \mathbf{~ 1 0 0 g})\end{array}$ & $\begin{array}{c}\text { Flavonoids } \\
(\mathbf{m g ~ C E} / \mathbf{g})\end{array}$ & $\begin{array}{c}\text { DPPH } \\
(\boldsymbol{\%})\end{array}$ & $\begin{array}{c}\text { FRAP } \\
\left(\boldsymbol{\mu m o l ~ F e} \mathbf{m}^{2+} / \mathbf{g}\right)\end{array}$ & $\begin{array}{c}\boldsymbol{\beta} \text {-carotene\& Linoleic } \\
\text { acid assay }(\boldsymbol{\%})\end{array}$ \\
\hline $\mathrm{T}_{0}$ & $99.00 \pm 4.45 \mathrm{~d}$ & $2.13 \pm 0.09 \mathrm{c}$ & $31.00 \pm 1.27 \mathrm{c}$ & $167.00 \pm 7.51 \mathrm{c}$ & $29.00 \pm 1.18 \mathrm{c}$ \\
$\mathrm{T}_{1}$ & $238.00 \pm 10.94 \mathrm{c}$ & $2.50 \pm 0.10 \mathrm{~b}$ & $45.00 \pm 1.93 \mathrm{~b}$ & $398.00 \pm 17.51 \mathrm{~b}$ & $37.00 \pm 1.70 \mathrm{~b}$ \\
$\mathrm{~T}_{2}$ & $341.00 \pm 16.02 \mathrm{~b}$ & $2.68 \pm 0.10 \mathrm{ab}$ & $49.00 \pm 2.20 \mathrm{ab}$ & $401.00 \pm 18.44 \mathrm{~b}$ & $40.00 \pm 1.88 \mathrm{ab}$ \\
$\mathrm{T}_{3}$ & $413.00 \pm 19.82 \mathrm{a}$ & $2.91 \pm 0.12 \mathrm{a}$ & $51.00 \pm 2.39 \mathrm{a}$ & $450.00 \pm 21.60 \mathrm{a}$ & $43.00 \pm 2.10 \mathrm{a}$ \\
\hline
\end{tabular}

Values expressed are means \pm standard deviation; $\mathrm{T}_{0}$ : Wheat Flour (Control); $\mathrm{T}_{1}: 5 \%$ fenugreek seeds powder supplemented wheat flour; $\mathrm{T}_{2}$ : $10 \%$ fenugreek seeds powder supplemented wheat flour; $\mathrm{T}_{3}: 15 \%$ fenugreek seeds powder supplemented wheat flour.

Table 5. Effect of treatments and storage on volume and aroma of supplemented bread

\begin{tabular}{|c|c|c|c|c|c|c|c|c|}
\hline \multirow{2}{*}{ Treatments } & \multicolumn{4}{|c|}{ Volume } & \multicolumn{4}{|c|}{ Aroma } \\
\hline & 0 hours & 24 hours & 48 hours & 72 hours & O hours & 24 hours & 48 hours & 72 hours \\
\hline $\mathrm{T}_{0}$ & $7.39 \pm 0.04$ & $7.21 \pm 0.13$ & $7.02 \pm 0.16$ & $6.90 \pm 0.12$ & $7.26 \pm 0.18$ & $7.02 \pm 0.15$ & $6.81 \pm 0.16$ & $6.74 \pm 0.12$ \\
\hline $\mathrm{T}_{1}$ & $7.29 \pm 0.04$ & $7.14 \pm 0.08$ & $6.95 \pm 0.05$ & $6.78 \pm 0.12$ & $7.11 \pm 0.18$ & $6.86 \pm 0.20$ & $6.57 \pm 0.16$ & $6.51 \pm 0.14$ \\
\hline $\mathrm{T}_{2}$ & $7.19 \pm 0.12$ & $7.06 \pm 0.10$ & $6.86 \pm 0.07$ & $6.68 \pm 0.10$ & $7.08 \pm 0.12$ & $6.85 \pm 0.18$ & $6.54 \pm 0.19$ & $6.48 \pm 0.17$ \\
\hline $\mathrm{T}_{3}$ & $7.02 \pm 0.09$ & $6.86 \pm 0.14$ & $6.74 \pm 0.09$ & $5.57 \pm 0.04$ & $7.01 \pm 0.20$ & $6.77 \pm 0.12$ & $6.48 \pm 0.21$ & $6.40 \pm 0.19$ \\
\hline
\end{tabular}

Values expressed are means \pm standard deviation; $\mathrm{T}_{0}$ : Wheat Flour (Control); $\mathrm{T}_{1}: 5 \%$ fenugreek seeds powder supplemented wheat flour; $\mathrm{T}_{2}$ : $10 \%$ fenugreek seeds powder supplemented wheat flour; $\mathrm{T}_{3}: 15 \%$ fenugreek seeds powder supplemented wheat flour.

Table 6. Effect of treatments and storage on taste and crust color of supplemented bread

\begin{tabular}{|c|c|c|c|c|c|c|c|c|}
\hline \multirow{2}{*}{ Treatments } & \multicolumn{4}{|c|}{ Taste } & \multicolumn{4}{|c|}{ Crust color } \\
\hline & O hours & 24 hours & 48 hours & 72 hours & 0 hours & 24 hours & 48 hours & 72 hours \\
\hline $\mathrm{T}_{0}$ & $7.62 \pm 0.06$ & $7.23 \pm 0.13$ & $6.90 \pm 0.21$ & $6.80 \pm 0.18$ & $7.52 \pm 0.03$ & $7.28 \pm 0.16$ & $7.06 \pm 0.14$ & $6.92 \pm 0.20$ \\
\hline $\mathrm{T}_{1}$ & $7.12 \pm 0.12$ & $6.82 \pm 0.13$ & $6.52 \pm 0.08$ & $6.38 \pm 0.07$ & $7.32 \pm 0.10$ & $7.13 \pm 0.09$ & $6.96 \pm 0.09$ & $6.88 \pm 0.15$ \\
\hline $\mathrm{T}_{2}$ & $7.02 \pm 0.08$ & $6.67 \pm 0.10$ & $6.40 \pm 0.05$ & $6.30 \pm 0.16$ & $7.23 \pm 0.12$ & $7.07 \pm 0.13$ & $7.00 \pm 0.07$ & $6.83 \pm 0.17$ \\
\hline $\mathrm{T}_{3}$ & $6.91 \pm 0.15$ & $6.62 \pm 0.16$ & $6.36 \pm 0.13$ & $6.24 \pm 0.11$ & $7.01 \pm 0.15$ & $6.81 \pm 0.15$ & $6.66 \pm 0.12$ & $6.62 \pm 0.14$ \\
\hline
\end{tabular}

Values expressed are means \pm standard deviation; $\mathrm{T}_{0}$ : Wheat Flour (Control); $\mathrm{T}_{1}: 5 \%$ fenugreek seeds powder supplemented wheat flour; $\mathrm{T}_{2}$ : $10 \%$ fenugreek seeds powder supplemented wheat flour; T3: $15 \%$ fenugreek seeds powder supplemented wheat flour.

Table 7. Effect of treatments and storage on overall acceptability of supplemented bread

\begin{tabular}{lcccc}
\hline \multirow{2}{*}{ Treatments } & \multicolumn{4}{c}{ Time (Hours) } \\
\cline { 2 - 5 } & $\mathbf{0}$ & $\mathbf{2 4}$ & $\mathbf{4 8}$ & $\mathbf{7 2}$ \\
\hline $\mathrm{T}_{0}$ & $7.46 \pm 0.15$ & $7.22 \pm 0.17$ & $7.07 \pm 0.14$ & $6.89 \pm 0.10$ \\
$\mathrm{~T}_{1}$ & $7.28 \pm 0.12$ & $7.02 \pm 0.20$ & $6.74 \pm 0.18$ & $6.74 \pm 0.10$ \\
$\mathrm{~T}_{2}$ & $7.23 \pm 0.18$ & $6.97 \pm 0.22$ & $6.74 \pm 0.12$ & $6.74 \pm 0.15$ \\
$\mathrm{~T}_{3}$ & $7.08 \pm 0.08$ & $6.83 \pm 0.18$ & $6.59 \pm 0.15$ & $6.59 \pm 0.10$ \\
\hline Values expressed are means + standard deviation; $\mathrm{T}_{0} \cdot$ Wheat Flour $\left(\right.$ Control); $\mathrm{T}_{1} \cdot 5 \%$ fenugreek seeds powder supplemented wheat flour; $\mathrm{T}_{2}$.
\end{tabular}

Values expressed are means \pm standard deviation; $\mathrm{T}_{0}$ : Wheat Flour (Control); $\mathrm{T}_{1}: 5 \%$ fenugreek seeds powder supplemented wheat flour; $\mathrm{T}_{2}$ : $10 \%$ fenugreek seeds powder supplemented wheat flour; $\mathrm{T}_{3}: 15 \%$ fenugreek seeds powder supplemented wheat flour. 
QE $\mu \mathrm{g} / \mathrm{g}$ of fenugreek (Bukhari et al., 2008). In an earlier study Ishtiaque et al. (2013) also found flavonoid content (5.80 $\mathrm{mg} \mathrm{QE} / \mathrm{g}$ ) in fenugreek seeds and supplementation in wheat flour resulted in increased flavonoid content. Similarly, Dixit et al. (2005) observed that antioxidant activity in fenugreek seeds may be due to presence of polyphenols and flavonoids. The DPPH assay is being used to determine the free radical scavenging effect of natural antioxidant. The bleaching of DPPH absorption indicated the capacity of the test drugs to scavenge free radicals independently (Subhashini et al., 2011; Dua et al., 2013). Likewise, Belguith-Hadriche et al. (2010) observed antioxidant activity of fenugreek seeds extract by estimating its ability to scavenge DPPH and observed result i.e. $89.91 \pm 3.09 \%$. Reducing power demonstrated the electron donor properties of fenugreek and then neutralized the free radicals by converting into stable products. A study was carried out by Khole et al. (2014) to separate and characterize bioactive molecules from germinated fenugreek seeds. Ethyl acetate, water and nbutanol were used for extraction purpose and the results for FRAP assay were obtained as $1.27 \pm 0.02,131.027 \pm 11.05$ and $0.14 \pm 0.007 \mathrm{mM}$ AEAC, respectively. In a meta-analysis, fenugreek seeds powder extracted systematically to evaluate FRAP assay at ambient temperature by selecting solvents of varying polarity such as methanol, dichloromethane, hexane and water and found it in the range of $0.135 \pm 0.05$ to $77.352 \pm 0.62 \mathrm{TE} \mathrm{mg} / \mathrm{g}$ (Kenny et al., 2013). The change in color of $\beta$ - carotene has been widely used to determine the antioxidant potential of different plants extract. As $\beta$ carotene molecules by process of oxidation lose their double bonds resulted in loss of yellow color of compound. Likewise, antioxidant activity of fenugreek fractions as measured by the bleaching of $\beta$-carotene used different fenugreek fractions like fenugreek husk, endosperm and seeds extracts that exhibited $73 \%, 6 \%$ and $22 \%$ activity when compared with the corresponding values of $95 \%$ for BHA (Naidu et al., 2011). Current results are in agreement with explorations of Subhashini et al. (2011) who determine the antioxidant activity of $70 \%$ ethanol extract of fenugreek by $\beta$ - carotene bleaching method. The extract was employed in the range of $25-400 \mathrm{mg} / \mathrm{mL}$ and by adding more quantity of the extract, absorbance was decreased and the reason behind was inhibition of bleaching of the color $\beta$ - carotene. Fenugreek extracts depicted inhibition at concentration of 0.202 $\mathrm{mg} / \mathrm{mL}$. The present findings of bread chemical composition are compatible with the previous studies like supplemented bread with fenugreek seeds increased total protein, fat, ash and fiber, while decreased moisture content and carbohydrates (Mahmoud, 2013). Similar findings were reported by Kasaye and Jha (2015) who found high fat, fiber and protein content in bread prepared with flour supplemented with fenugreek seeds powder. The shielding impact of fenugreek against chronic diseases has been accredited to the antioxidant potential of its total phenolic and flavonoid content like alkaloids, flavonoids and saponins (Kumar et al., 2013). The flavonoids contents in wheatfenugreek supplemented bread were found higher when compared with control bread because fenugreek powder is a better source of flavonoid compounds than wheat flour. However, wheat-fenugreek flour bread has flavonoids content lower than supplemented flour. The possible reason of loss during processing conditions like baking, there might be loss of flavonoid compounds due to thermal process that leads to reduce antioxidant activities (Dietrych-Szostak and Oleszek, 1999).

The DPPH value for bread prepared from wheat flour found lower than fenugreek-wheat supplemented bread. The bread prepared from refined and whole wheat flour had DPPH values in the range of 2.83 to $3.90 \mu \mathrm{mol} \mathrm{TE} / \mathrm{g}$ and 2.79 to 4.05 $\mu \mathrm{mol} \mathrm{TE} / \mathrm{g}$ (Yu et al., 2013). However, average DPPH value was observed $64.2 \%$ in fenugreek supplemented chicken patties due to higher activity of fenugreek (Devatkal et al., 2012). In a previous study, higher content of $\beta$-carotene $(22.5 \mathrm{mg} / 100 \mathrm{~g})$ observed in low humidity air dried fenugreek compared to radiofrequency dryer dried sample (6.2 $\mathrm{mg} / 100 \mathrm{~g} ; 76.2 \mathrm{mg} / 100 \mathrm{~g})$ and hot air dried fenugreek $(6.0$ $\mathrm{mg} / 100 \mathrm{~g} ; 148.1 \mathrm{mg} / 100 \mathrm{~g}$ ) (Naidu et al., 2012). The supplementation of fenugreek seeds in the diet of rats prevented enzymatic leakage, alter lipid peroxidation and enhanced antioxidant potential (Thirunavukkarasu et al., 2003). So fenugreek seeds can be a potential source of bioactive compounds and addition of fenugreek powder in rats diet @ of $1 \mathrm{~g} / \mathrm{kg}$ of body weight lowered lipid peroxidation and improved significant system (Annida and Prince, 2004). No bioactive components were detected in paratha prepared with wheat flour. However, $\beta$-carotene content found slightly higher when $25 \%$ of normal fenugreek incorporated in wheat flour (Sudha et al., 2013).

The current findings of bread sensory evaluation are well supported by earlier studies of Hooda and Jood, (2004), Hefnawy et al. (2012), Rasool et al. (2013) and Kasaye and Jha, (2015). The supplementation of legume flours affects the qualitative parameters of baked products like bread volume. The other bakery product like pastries volume was found to be decreased mainly due to decrease in the amount of gluten caused by the addition of materials from which it is not possible to isolate gluten. By lowering the amount of gluten, the ability to keep ferment gas during the rising of dough is also lowered and consequently it influences as lower volume (Bojnanska et al., 2010). When fenugreek was added in wheat flour it modified the sensory attributes like taste and mouth feel of the product. There was a decreasing trend for odor and taste, probably due to fenugreek flavor (Hooda and Jood, 2004). The desirable aroma of fenugreek seeds came from polysaccharides (galactomannan), volatile oils and alkaloids, such as choline and trigonelline (Rasool et al., 2013). Color 
of the baked product depends on physicochemical properties of the dough $(\mathrm{pH}$, water content, amino acid content and reducing sugars) and processing conditions applied during baking process like relative humidity, temperature, air speed, modes of heat transfer (Zanoni et al., 1995). Likewise, with increasing fenugreek seed flour in wheat flour, dull brown color of the bread was observed (Chauhan and Sharma, 2000). Conclusion: The supplementation of fenugreek seeds powder in wheat flour resulted in improved nutritional and antioxidant status with acceptable quality of bread. It was observed that crude protein, crude fiber and ash content of bread increased with the addition of fenugreek powder. Similarly, polyphenol and flavonoid content and antioxidant activity of bread found increasing trend with increasing the supplementation level. It is concluded from the present study that fenugreek seeds powder can be added upto $15 \%$ in bread making flour that increased its nutritional profile and antioxidant activity without affecting sensory attributes adversely.

\section{REFERENCES}

AACC. 2000. Approved Methods of the American Association of Cereal Chemist, $9^{\text {th }}$ Ed. Association of Official Analytical Chemist. Washington DC.

Adegoke, G., M.V. Kumar, A.G. Krishna, M. Varadaraj, K. Sambaiah and B. Lokesh. 1998. Antioxidants and lipid oxidation in foods: A critical appraisal. J. Food Sci. Tech. 35:283-298.

Ahari, D.S., A.K. Kashi, M.R. Hassandokht, A. Amri and K. Alizadeh. 2009. Assessment of drought tolerance in Iranian fenugreek landraces. J. Food Agric. Environ. 7:414-419.

Ali, A., M.I. Waly, N. Bhatt and N.A. Al-Saady. 2015. Proximate and phytochemical composition and antioxidant properties of indigenous landraces of omani fenugreek seeds. Afr. J. Tradit. Complement. Altern. Med. 12:149-154.

Annida, B. and S.M. Prince. 2004. Supplementation of fenugreek leaves lower lipid profile in streptozotocininduced diabetic rats. J. Med. Food. 7:153-156.

Belguith-Hadriche, O., M. Bouaziz, K. Jamoussi, A. El Feki, S. Sayadi and F. Makni-Ayedi. 2010. Lipid-lowering and antioxidant effects of an ethyl acetate extract of fenugreek seeds in high-cholesterol-fed rats. J. Agric. Food Chem. 58:2116-2122.

Benzie, I.F. and J. Strain. 1996. The ferric reducing ability of plasma (FRAP) as a measure of antioxidant power: the FRAP assay. Anal. Biochem. 239:70-76.

Betty, R. 2008. The many healing virtues of fenugreek. Spice India 1:17-19.

Bojnanska, T., M. Tokar and R. Gazar. 2010. Pharinographic characteristics of wheat dough with natural additives. J. Food Phy. 23:9-12.
Bukhari, S.B., M.I. Bhanger and S. Memon. 2008. Antioxidative Activity of Extracts from Fenugreek. Pak. J. Anal. Environ. Chem. 9:78-83.

Chauhan, G. and H. Sharma. 2000. Physico-chemical and rheological quality characteristics of fenugreek (Trigonella foenum-graecum L.) supplemented wheat flour. J. Food Sci. Tech. 37:87-90.

Devatkal, S.K., P.R. Thorat, M. Manjunatha and R.K. Anurag. 2012. Comparative antioxidant effect of aqueous extracts of curry leaves, fenugreek leaves and butylated hydroxytoluene in raw chicken patties. J. Food Sci. Tech. 49:781-785.

Dietrych-Szostak, D. and W. Oleszek. 1999. Effect of Processing on the flavonoid content in buckwheat (Fagopyrum esculentum Moench) grain. J. Agric. Food Chem. 47:4384-4387.

Dixit, P., S. Ghaskadbi, H. Mohan and T. Devasagayam. 2005. Antioxidant properties of germinated fenugreek seeds. Phytother. Res. 19:977-983.

Dua, A., S. Vats, V. Singh and R. Mahajan. 2013. Protection of biomolecules against in vitro oxidative damage by the antioxidants from methanolic extract of Trigonella foenum-graecum seeds. Int J. Pharm. Sci. Res. 4:30803086.

Hefnawy, T., G. El-Shourbagy and M. Ramadan. 2012. Impact of adding chickpea (Cicer arietinum L.) flour to wheat flour on the rheological properties of toast bread. Int. Food Res. J. 19:521-525.

Hooda, S. and S. Jood. 2004. Nutritional evaluation of wheatfenugreek blends for product making. Plant Foods Hum. Nutr. 59:149-154.

Ishtiaque, S., N. Khan, M.A. Siddiqui, R. Siddiqi and S. Naz. 2013. Antioxidant potential of the extracts, fractions and oils derived from oilseeds. Antioxidants 2:246-256.

Kasaye, A.T. and Y.K. Jha. 2015. Evaluation of composite blends of fermented fenugreek and wheat flour to assess its suitability for bread and biscuit. Int. J. Nut. Food Sci. 4:29-35

Kenny, O., T. Smyth, C. Hewage and N. Brunton. 2013. Antioxidant properties and quantitative UPLC-MS analysis of phenolic compounds from extracts of fenugreek (Trigonella foenum-graecum) seeds and bitter melon (Momordica charantia) fruit. Food Chem. 141:4295-4302.

Khan, M.R., F.M. Anjum, T. Zahoor and H. Nawaz. 2009. Biochemical and Technological characterization of Pakistani spring wheats. Pak. J. Agri. Sci. 46:271-279.

Khole, S., S. Chatterjee, P. Variyar, A. Sharma, T. Devasagayam and S. Ghaskadbi. 2014. Bioactive constituents of germinated fenugreek seeds with strong antioxidant potential. J. Funct. Foods 6:270-279.

Kumar, G.P., T. Anand, D. Singsit, F. Khanum and K. Anilakumar. 2013. Evaluation of antioxidant and antifatigue properties of Trigonella foenum-graecum L. in 
rats subjected to weight loaded forced swim test. Pharmacogn. J. 5:66-71.

Lawless, H.T. and H. Heymann. 1998. Sensory evaluation of food: principles and practices. New York, NY: Chapman \& Hall; pp. 341-378. Chap. 10.

Liu, X., M. Dong, X. Chen, M. Jiang, X. Lv and G. Yan. 2007. Antioxidant activity and phenolics of an endophytic Xylaria sp. from Ginkgo biloba. Food Chem. 105:548554.

Mahfouz, S.A., S.M. Elaby and H.Z. Hassouna. 2012. Effects of some legumes on hypercholesterolemia in rats. J. Am. Sci. 8:1453-1460.

Mahmoud, M.Y. 2013. Effect of high protein diet containing fortified bread with fenugreek and nigella sativa seeds on rats suffering from diabetes. Pak. J. Nutr. 12:736-747.

Mehrafarin, A., A. Qaderi, S. Rezazadeh, H. Naghdi-Badi, G. Noormohammadi and E. Zand. 2010. Bioengineering of important secondary metabolites and metabolic pathways in fenugreek (Trigonella foenum-graecum L.). J. Med. Plants. 9:1-18.

Meilgaard, M., G. Civille and B. Carr. 2007. Overall difference tests: does a sensory difference exist between samples. Sensory Evaluation Techniques 4:63-104.

Mueen-Ud-Din, G., F.M.Anjum. S.U. Rehman and H. Nawaz. 2009. Studies on organic acids and minerals content of sourdough naans made from different extraction rate wheat flours and starter cultures. Pak. J. Nutr. 8:877-881.

Naidu, M.M., B. Shyamala, J.P. Naik, G. Sulochanamma and P. Srinivas. 2011. Chemical composition and antioxidant activity of the husk and endosperm of fenugreek seeds. LWT-Food Sci. Tech. 44:451-456.

Naidu, M.M., H. Khanum, G. Sulochanamma, H.B. Sowbhagya, U.H. Hebbar, M. Prakash and P. Srinivas. 2012. Effect of drying methods on the quality characteristics of fenugreek (Trigonella foenumgraecum) greens. Drying Tech. 30:808-816.

Oktay, M., I. Gulcin and O.I. Kufrevioglu. 2003. Determination of in vitro antioxidant activity of fennel (Foeniculum vulgare) seeds extracts. LWT-Food Sci. Tech. 36:263-271.

Premanath, R., J. Sudisha, N. Lakshmi Devi and S. Aradhya. 2011. Antibacterial and antioxidant activities of fenugreek (Trigonella foenum-graecum L.) leaves. Res. J. Med. Plants 5:695-705.

Raju, J. and R. Bird. 2006. Alleviation of hepatic steatosis accompanied by modulation of plasma and liver TNF- $\alpha$ levels by Trigonella foenum-graecum (fenugreek) seeds in Zucker obese (fa/fa) rats. Int. J. Obesity 30:1298-1307.
Rasool, A.A., D.A. Abdulkhaleq and D.A. Sabir. 2013. Effects of using different percentages of fenugreek flour to improve the sensory, rheological properties and keeping quality in maize dough to produce gluten-free breads. J. Agri. Sci. Tech. 3:380-384.

Rusak, G., D. Komes, S. Likic, D. Horzic and M. Kovac. 2008. Phenolic content and antioxidative capacity of green and white tea extracts depending on extraction conditions and the solvent used. Food Chem. 110:852858.

Sethi, G., K.S. Ahn and B.B. Aggarwal. 2008. Targeting nuclear factor- $\kappa \mathrm{B}$ activation pathway by thymoquinone: role in suppression of antiapoptotic gene products and enhancement of apoptosis. Mol. Cancer Res. 6:10591070.

Singleton, V.L., R. Orthofer and R.M. Lamuela-Raventos. 1999. Analysis of total phenols and other oxidation substrates and antioxidants by means of folin-ciocalteu reagent. Methods Enzymol. 299:152-178.

Steel, R.G.D., J.H. Torrie and D. Dickey. 1997. Principles and procedures of statistics: a biometrical approach, $3^{\text {rd }} \mathrm{Ed}$. McGraw Hill Book Co., Inc., New York.

Subhashini, N., A. Thangathirupathi and N. Lavanya. 2011. Antioxidant activity of Trigonella foenum-graecum using various in vitro and ex vivo models. Int. J. Pharm. Pharm. Sci. 3:96-102.

Sudha, M., S.W. Eipson, H. Khanum, M.M. Naidu and G.V. Rao. 2013. Effect of normal/dehydrated greens on the rheological, microstructural, nutritional and quality characteristics of paratha-an Indian flat bread. J. Food Sci. Tech. 52:840-848.

Thirunavukkarasu, V., C. Anuradha and P. Viswanathan. 2003. Protective effect of fenugreek (Trigonella foenumgraecum) seeds in experimental ethanol toxicity. Phytother. Res. 17:737-743.

Yaser, A.J., A. Muneer, B. Abdelhafid, C.S. Daoudi and L. Hammadi. 2013. Chemical and phytochemical analysis of some antidiabetic plants in Yemen. Int. Res. J. Pharm. 4:72-76.

$\mathrm{Yu}$, L. and A.L. Nanguet. 2013. Comparison of antioxidant properties of refined and whole wheat flour and bread. Antioxidants 2:370-383.

Zanoni, B., C. Peri and D. Bruno. 1995. Modeling of browning kinetics of bread crust during baking. LWTFood Sci. Tech. 28:604-609.

Zhishen, J., T. Mengcheng and W. Jianming. 1999. The determination of flavonoid contents in mulberry and their scavenging effects on superoxide radicals. Food Chem. 64:555-559. 